\title{
JAPAN-AUSTRALIA SECURITY RELATIONS AND THE RISE OF CHINA: PURSUING THE "BILATERAL-PLUS" APPROACHES ${ }^{1}$
}

\author{
Yusuke Ishihara ${ }^{2}$ \\ The National Institute for Defense Studies (NIDS), Japan
}

\begin{abstract}
:
Japan-Australia security relations have been visibly growing for the past six years since the landmark Joint Declaration on Security Cooperation was announced in March 2007. Although many scholars point out that the rise of China is a key driving force for this emerging security partnership, there is no updated, comprehensive and detailed study which focuses on the question of how and why Japan-Australia cooperation especially since 2007 can be related to their joint approaches to China. In answering this question this paper makes the case that Japan-Australia joint approaches towards China should be understood in a broader perspective beyond the bilateral context if one aspires to understand the nature of their security relations. Such broader perspectives can be termed as "bilateral-plus" approaches in which Japan and Australia seek to embed their bilateral cooperation into a wider formula of their trilateral cooperation with the U.S., and their regional multilateral efforts.
\end{abstract}

Keywords: Japan, Australia, Rise of China, Bilateral-Plus, Hedge, Trilateral Cooperation.

\section{Resumen:}

Las relaciones de seguridad Japón-Australia han ido profundizándose ostensiblemente en los últimos seis años desde el hito de la Declaración Conjunta sobre Cooperación en Seguridad anunciada en marzo del 2007. Aunque numerosos académicos apuntan al hecho de que es el ascenso de China el principal factor aglutinante en la incipiente asociación, no existen estudios detallados, integrales y actualizados, sobre cómo y porqué la cooperación Japón-Australia, especialmente desde el 2007, ha de relacionarse con sus aproximaciones comunes a China. Este artículo intenta responder argumentando que las estrategias comunes entre Japón y Australia hacia China han de ser entendidas dentro de una perspectiva amplia más allá de los parámetros estrictamente bilaterales, si uno realmente aspira a entender la naturaleza de sus relaciones de seguridad. Aproximaciones de este tipo, teniendo en cuenta una perspectiva más amplia, podrían definirse como "bilateral-plus", donde Japón y Australia buscan integrar su cooperación bilateral dentro de una fórmula más amplia, ya sea el marco de cooperación trilateral con los EEUU, o esfuerzos de cooperación regional de carácter multilateral.

Palabras clave: Japón, Australia, ascenso de China, Bilateral-Plus, contención, cooperación trilateral.

\section{Copyright $@$ C UNISCI, 2013.}

Las opiniones expresadas en estos artículos son propias de sus autores, y no reflejan necesariamente la opinión de UNISCI. The views expressed in these articles are those of the authors, and do not necessarily reflect the views of UNISCI

\footnotetext{
${ }^{1}$ The analysis of this paper reflects only the author's personal perspectives, not necessarily the official position of the National Institute for Defense Studies or the Government of Japan.

${ }^{2}$ Yusuke Ishihara is Fellow at the Policy Studies Department of the The National Institute for Defense Studies (NIDS), Japan.

E-mail: ishihara-yu@nids.go.jp.
}

http://dx.doi.org/10.5209/rev_UNIS.2013.n32.4479] 


\section{Introduction}

A number of indicators suggest that Australia is Japan's second, if not most important, security partner in the Asia-Pacific region. As the best example of this, Prime Minister Shinzo Abe during his first term and then Prime Minister John Howard signed the historic Joint Declaration on Security Cooperation in March 2007, which was the first that Japan agreed with any country other than its long standing ally, the United States. ${ }^{3}$ Since then, Japan and Australia have succeeded in establishing the institutional foundations for furthering security cooperation including the conclusion of treaties on logistic support and intelligence sharing. On the current horizon of Japan's international partnership building, no other bilateral relation, excepting the Japan-U.S. alliance itself, has matched so far relations between Japan and Australia both in depth and in the range of security and defense interactions.

Worth highlighting is the fact that such closeness is observable not only in their words, but more importantly, in their deeds too. A good example is the response to the March 2011 triple disasters, where Australia offered its urban Search and Rescue team, three C-17s and remotely pilotable water pump equipments to Japan. ${ }^{4}$ The $\mathrm{C}-17 \mathrm{~s}$ operated in close cooperation with US forces and the Japanese Self-Defense Force (SDF), turning the Australian Defence Force (ADF) into the only military unit operating in such close and substantial manner except for the United States. In fact, the total volume of transported material offered by Australia reached about 500 tons. This is a substantial volume when compared to the 3,700 tons that the Air Self-Defense Force (ASDF) transported in much longer operational periods. ${ }^{5}$

Given such close collaboration, it can hardly be a surprise that a number of experts have explored the reasons why Japan and Australia are moving into such direction. In fact, many observers in Japan, Australia and elsewhere link the rationale for this growing bilateral cooperation to the China factor. Among Japanese experts, Yoshinobu Yamamoto argues that Japan-Australia security relations are developing as a "collective hedging" aimed at China, while Takashi Terada characterizes the two countries as putting China "in check". ${ }^{6}$ Likewise, a Japan hand in Australia, Aurelia George Mulgan, describes the motivations behind the Japan-Australia relations through the lenses of Neo-Realism and conceptualizes the bilateral cooperation as a "containment coalition" against China. ${ }^{7}$ Similarly the well-known JapanAustralia watcher and IR scholar, William Tow uses his own concept of "competitive strategic geometry" to characterize the bilateral partnership in the context of dealing with China.

\footnotetext{
${ }^{3}$ Ministry of Foreign Affairs of Japan (MOFA): "Japan-Australia Joint Declaration on Security Cooperation”, Tokyo (March 2007), at http://www.mofa.go.jp/region/asia-paci/australia/joint0703.html.

${ }^{4}$ Australian Department of Defence: "Operation Pacific Assist", at http://www.defence.gov.au/op/pacificassist/index.htm.

5 "Australia's Security Policy", in National Institute for Defense Studies(eds.) (2013): East Asian Strategic Review 2013 (Japanese version), Tokyo, Prime Station, p. 87.

${ }^{6}$ Yamamoto, Yoshinobu: "Triangularity and US-Japanese relations: Collaboration, collective hedging and identity politics", in Tow, William; Thomson, Mark, Yamamoto, Yoshinobu, and Limaye Sato (eds.) (2007): Asia-Pacific Security-US, Australia and Japan and the New Security Triangle, New York, Routledge, p. 77. Terada, Takashi: "Evolution of the Australia-Japan Security Partnership Toward a Softer Triangle Alliance with the United States?”,Asie.Visions, vol. 35 (October 2010), p.9.

${ }^{7}$ Mulgan, Aurelia George: "Breaking the Mould-Japan's subtle Shift from Exclusive Bilateralism to Modest Minilateralism”, Contemporary Southeast Asia, vol. 30, no. 1 (April 2008), p. 54.

${ }^{8}$ Tow, William T: "Asia's Competitive "Strategic Geometries": The Australian Perspective 1", Contemporary Southeast Asia, vol. 30, no.1 (April 2008), pp. 29-51.
} 
Although these experts explicitly consider Japan-Australia relations as an expression of their joint China policy, the logic of these arguments is either not very clear or not thoroughly investigated. Most importantly various concepts developed to analyze Japan-Australia relations are employed without sufficient explanation of what these might suggest about the linkage between Japan-Australia relations and China. Furthermore, what makes this question more puzzling is the two countries' apparent divergence in perception and approach towards China. Nick Bisley, for example, is one among many scholars to point out that Japan and Australia have "palpably different attitudes" towards China and that unlike Japan, Australia "does not feel the PRC to be at all threatening to its interests". 9 If this is truly the case, what warrants us to say that Japan and Australia do cooperate closely for the purpose of dealing with the rise of China?

This paper directly addresses the question of why Japan-Australia security relations can be considered as a joint approach towards China. The conclusion of this paper is twofold. First, any analysis looking at Japan-Australia cooperation through the narrow bilateral context will never sufficiently account for what the two countries are trying to achieve amidst the rise of China. In fact, the paper highlights that what the two countries are pursuing in strictly bilateral settings is either limited, underdeveloped or constrained in terms of effectiveness regarding their China policy. The second part of the paper's conclusion is that one should take a broader perspective in order to fully shed light on the China factor in Japan-Australia security cooperation. In other words, the paper argues that Japan and Australia do cooperate to deal with the rise of China not in strictly bilateral manner but in much broader "bilateralplus" contexts such as trilateral cooperation with the U.S., multilateral institution building and assistance towards third countries. Without placing the Japan-Australia cooperation in such broader contexts one could never grasp the full picture of Japan-Australia's joint approach towards China.

This paper offers two perhaps unique contributions to the study on Japan-Australia relations. The first derives from the paper's timeliness in being written in 2013, an especially high time for examining Japan-Australia security relations. This is so because most of the agendas set by the landmark Joint Declaration on Security Cooperation in March 2007 have now been largely implemented and the two countries are aspiring to enter a new phase of their bilateral cooperation. In this sense, 2013 is an appropriate year for doing some stocktaking upon what the two countries have achieved for the past several years. Second, this paper offers a comprehensive and detailed study about all the aspects of Japan-Australia joint approaches towards China. By so doing, the paper offers a full picture of how Japan and Australia deal with China together as no other study has done to date.

\section{Background: Progress of Japan-Australia Security Relations}

In retrospect it cannot be an exaggeration to note that Japan-Australia relations have marched a long road from the ashes of the Second World War to the present stage of close and active cooperation. In the immediate aftermath of the War, Australia, which was bombed by a foreign military force for the first time in its history and fought Japanese troops on the Papua New Guinea Island, was also one of the countries demanding the harshest treatment for postWar Japan. In fact, Australia's concerns over Japan were of such magnitude that a real policy

${ }^{9}$ Bisley, Nick: "The Japan-Australia security declaration and the changing regional security setting: wheels, webs and beyond?", Australian Journal of InternationalAffairs, vol. 62, no. 1 (March 2008), p. 47. 
issue was to attempt securing as strong a security guarantee as possible from the United States, concluding thus the ANZUS treaty in $19511^{10}$

Over the decades of Cold War, however, Japan and Australia did slowly develop a limited and low-key frame of security cooperation in two areas. The first one was in intelligence exchange. Cooperation in such area gradually emerged over the course of the 1950s and 60s driven by the combination of multiple factors, among which were Australia's concerns over Southeast Asia, in particular the "confrontation" of Sukarno regime in Indonesia as well as Japan's growing role and unique perspectives on Indonesia, China and other regional countries. ${ }^{11}$ As such bilateral exchanges matured and expanded, the level of cooperation reached the point where the two countries established the liaison arrangement between Australian Secret Intelligence Service (ASIS) and Japanese Cabinet Research Office, or Naicho in $1976 .{ }^{12}$ Similarly the 1970 s saw the liaison arrangement between Australian Joint Intelligence Organisation (JIO) and Japanese Defense Agency, or Boeicho. ${ }^{13}$

Another field of security cooperation that Japan and Australia explored during the Cold War had to do with mechanisms of regional cooperation. In the 1970s and 1980s Japan and Australia engaged in intensive dialogues on regional cooperation involving both policy planners and academics and which both in practical and intellectual terms set the ground for their diplomatic collaboration towards the creation of APEC in $1989 .{ }^{14}$

By contrast, after the end of the Cold War, the two countries started building an impressing record of more active cooperation. Indeed there is a wide range of areas in which the two countries pursued cooperation over the two decades of the post-Cold War period but International Peace Cooperation activity has perhaps played the pioneering role in this regard. In 1992 Japan for the first time dispatched its Self Defense Force (SDF) units to PKO in Cambodia, the military section of which was commanded by the Australian Army Lieutenant General John Sanderson. ${ }^{15}$ Later in 2000, Japan again sent its SDF personnel to participate in PKO in East Timor, both initiated and led by Australian government providing at its peak as much as a 5,650 strong force. ${ }^{16}$ Furthermore, when Japan dispatched an about 500 men strong SDF engineer unit to Samawa, Muthan-na Province Iraq in 2004 to 2006, Australia operationally cooperated with the deployed SDF troops offering to maintain the security environment in the city. ${ }^{17}$ More recently Australia and Japan cooperated in PKO in South Sudan, for which two Australian officers worked within the Japanese PKO office to provide information relevant to the SDF's work and to facilitate communications with UNMISS command and other international organizations. ${ }^{18}$

Another area of active cooperation is Humanitarian Assistance and Disaster Relief (HA/DR). In the wake of the Boxing Day Tsunami hitting a significant part of Southeast Asia

\footnotetext{
${ }^{10}$ Iwamoto, Yujiro (1993): Ousutoraria no naiseito gaiko boei seisaku, Tokyo, Nihonhyoronsha.

${ }^{11}$ Walton, David: “Australia-Japan and the region, 1952-65: the beginnings of security policy networks, in Williams, Brad and Newman, Andrew (eds.) (2006): Japan, Australia and Asia-Pacific Security, New York, Routledge, pp. 9-29.

${ }^{12}$ Ball, Desmond: "Security cooperation between Japan and Australia: current elements and future prospects", in Williams and Newman,op. cit.,pp. 164-185.

${ }^{13}$ Ibid.

${ }^{14}$ Funabashi, Yoichi (1995): Asia Pacific Fusion Japan's Role in APEC, Tokyo, Chuokoronsha.

${ }^{15}$ National Institute for Defense Studies, op.cit.,p. 86.

${ }^{16}$ Ohnishi, Ken: "Coercive Diplomacy and Peace Operations: Intervention in East Timor", NIDS Journal of Defense and Security, no. 13 (December 2012), p. 64.

${ }^{17}$ Ministry of Defense Japan (2006): Defense of Japan 2006 (Japanese version), Tokyo, Gyosei, p. 229.

${ }^{18}$ National Institute for Defense Studies, op.cit., p. 87.
} 
in December 2004, Japan and Australia formed the core group of countries along with the United States and India which provided vitally needed humanitarian supplies to the affected areas. ${ }^{19}$ As the introductory part of this paper already described, in the disaster relief operation in March 2011, Australia deployed its C-17 aircraft playing a substantial role in the transportation of Australian Search and Rescue team as well as the cargos and SDF units across Japan. ${ }^{20}$

While many security gatherings in the Asia Pacific are often characterized as a "talk shop", it would be safe to nickname the Japan-Australia partnership as a practical "action shop" given the increasing record of close and active cooperation. In 2007 the growing momentum of expanded joint efforts finally materialized in a more conscious decision to establish institutional arrangements which could improve bilateral cooperation when the two countries announced their Joint Declaration on Security Cooperation in March 2007. This institutionalization in search of a more robust and closer security partnership has been since 2007 largely successful in the following three aspects.

First, Japan and Australia have to a great extent matured the mechanism of both policy and the military-to-military dialogues. In terms of policy dialogues, Japan and Australia frequently hold a Two plus Two meeting $(2007,2008,2010,2012)$ while conducting a number of pol-pol/pol-mil/service-to-service meetings on a regular basis. ${ }^{21}$ In addition to those talks, the SDF and the ADF have begun conducting joint trainings such as the Nichi-Go Trident in which surface vessels, submarines and maritime surveillance aircraft from the Maritime Self Defense Force (MSDF) and the Royal Australian Navy (RAN) take part. ${ }^{22}$ During June-July of 2011, the F-15s of the ASDF and the F/A-18s of the Royal Australian Air Force (RAAF) conducted their first bilateral air combat training. These service-to-service interactions help mature their military relationship and enhance the interoperability of the two countries' defense forces. Japan does not have a closer and active military relationship with any other state excepting, needless to say, the United States.

The second successful aspect in their bilateral partnership has been in the field of legal arrangements. In fact, the two countries signed two legal agreements for closer bilateral cooperation in this area, the Information Security Agreement (ISA) and the Acquisition and Cross-Servicing Agreement (ACSA). ISA and ACSA are important legal frameworks which help enhance the interoperability between the two governments. The ISA was signed by the foreign ministers in 2012, and came into effect when diplomatic notes were exchanged in March 2013, while the ACSA was concluded in 2010, becoming effective in January $2013 .{ }^{23}$

The third element of success is the increasingly visible bipartisan support in both countries regarding the importance of Japan-Australia security relations. When bilateral security relations started their institutionalization in 2007, the personality of the leaders appeared to be playing important roles. In the case of Australia, John Howard was famous for his personal commitment to relations with Japan as demonstrated by many episodes earlier, as for example his vocal advocacy for closer cooperation with Japan even before his

\footnotetext{
${ }^{19}$ For the details of SDF's operation, see Japan Defense Agency (2007): Defense of Japan 2005 (Japanese version), Tokyo, Gyosei, pp. 251-259.

${ }^{20}$ National Institute for Defense Studies, op.cit., p. 87.

${ }^{21}$ Ibid., pp. 87-88.

${ }^{22}$ Ibid., p. 88.

${ }^{23}$ Carr, Bob: “Australia-Japan Information Security Agreement enters into force”, Media Release: Australian Minister for Foreign Affairs, 26 March 2013;

National Institute for Defense Studies, op.cit.,p. 88.
} 
inauguration in 1996. Reflecting this, “A Defence Update 2007”, the last major public defense document produced by his government,clearly stated that "Australia has no closer nor more valuable partner in the region than Japan". ${ }^{24}$ Likewise, the Japanese leader who signed the Joint Declaration with Mr. Howard was Shinzo Abe, who personally advocated for the idea of closer partnerships with like-minded democracies such as India and Australia. The strong personal commitments to the bilateral relations by both Mr. Howard and Mr. Abe appear indeed to have played a very important role.

The truth is, however, that for the past six years since the declaration, the successive governments in both countries have remained committed to advancing Japan-Australia security relations, surviving thus the bilateral partnership the historic change of government in Japan. Within a few days of its inauguration in 2009, the then newly elected Prime Minister Yukio Hatoyama met his Australian counterpart Prime Minister Kevin Rudd in New York and reassured the Australian side about the new government's intention to continue developing bilateral rations. ${ }^{25}$ As a matter of fact, it was the Democratic Party of Japan (DPJ)led government which maintained the two plus two and other bilateral mechanisms and concluded the aforementioned two treaties. In December 2012, the general election of the House of the Representatives in Japan returned the Liberal Democratic Party (LDP) to power through a land-slide victory, which brought Mr. Abe, the signer of the 2007 Declaration, back into the Japanese Premiership. In spite of his attacks on the DPJ's foreign policy, it is noteworthy that Prime Minister Abe has praised the DPJ for pursuing Japan-Australia cooperation in the same line he had laid out in his first term. ${ }^{26}$

Australia also experienced two transitions for the past six years, which have proved the resiliency of Japan-Australia security relations. In the first several months of the Rudd Government, it was widely perceived both in Australia and Japan that Kevin Rudd held a more lukewarm attitude towards Japan. This image was largely created when Mr. Rudd's first overseas trip including China, left out Japan. It turned out, however, that Kevin Rudd was committed to building upon the groundwork founded by his predecessor. On his first visit to Japan in June 2008, Mr. Rudd and then Prime Minister Yasuo Fukuda agreed to issue a Joint Statement on "Comprehensive, Strategic and Economic Partnership", which largely confirmed the existing bilateral momentum. Later on, after Mr. Rudd stepped down and the current Government by Julia Gillard was inaugurated, bilateral relations did not experience any downward turn. Under the leadership of Prime Minister Gillard, Japan was designated as Australia's "closest partner in Asia."27

This quick overview reveals that the year 2007 was a clear turning point with the Joint Declaration visibly accelerating Japan-Australia joint efforts to consciously develop institutions to improve bilateral security cooperation. In fact, the two countries have successfully developed policy dialogues, military exchanges as well as some political and legal foundations while further work for enhancing the bilateral relationship is still underway. Building upon such multifaceted success, Japan and Australia released another milestone document in September 2012, called "Common Vision and Objectives". The Vision Statement outlines a list of concrete action-items towards the end of further accelerating the

\footnotetext{
${ }^{24}$ Department of Defence Australia (2007): Australia's National Security: A Defence Update 2007, Canberra, Department of Defence, p. 19.

25 "Nichoshunokaidan", Gaiyo (Press Release by MOFA), 23 September 2009.

${ }^{26}$ Abe, Shinzo: “Asia's Democratic Security Diamond”, Project Syndicate, 27 December 2012.

${ }^{27}$ Carr, Bob: “Address to the Japan National Press Club”, Speech by Minister for Foreign Affairs, 18 May 2012.
} 
momentum created by the 2007 Joint Declaration ${ }^{28}$. The Vision Statement identified new areas of cooperation such as technology and equipment cooperation, defense capacitybuilding assistance and cooperation in the field of cyber security. Given such rapid developments in their bilateral relations, it should be no surprise that a number of analysts have been discussing the reasons why Japan and Australia are coming closer.

\section{Limits to Japan-Australia "Bilateral" Cooperation as a Common Policy vis-à-vis China}

Can the growing Japan-Australia security relations be regarded as a joint effort to deal directly with the rise of China? Japan, Australia and many other countries pursue a dual-track strategy known under various definitions as "engagement and balancing," "congagement," and "integration but hedge", whose essence lies in the behavior of many countries exploring at the same time engagement in parallel with hedging against risks coming from China. In fact, many scholars often claim that Japan and Australia cooperate for the sake of hedging against China. Hedging is an increasingly used concept in the contemporary Asia-Pacific security literature, defined by Evan Medeiros as "realist-style balancing in the form of external security cooperation with Asian states and national military modernization programs". ${ }^{29}$ In this context one agenda currently on the table of Japan-Australia cooperation that is worth close scrutiny is the ongoing Japan-Australia dialogue on technology and equipment cooperation. It is the following combination of two factors that encouraged Japan and Australia to engage in this kind of cooperation.

First, Japanese government recently changed its long-standing export control policy. For a long period the Japanese Government was known for applying an uniquely tight policy of control over arms export. In April 1967, then Japanese Prime Minister Eisaku Sato made remarks in the Diet that arms exports would not be approved if destined to any of the following three types of countries: communist states, states sanctioned by the UN resolutions and countries which were currently engaged or likely to be engaged in international conflicts. ${ }^{30}$ Sato's statement known as the three principles on the arms exports was further developed and turned in February 1976 into a fully established policy in the name of the peaceful character of the nation. Under the said policy, Japan decided (1) not to approve any arms exports to the aforementioned three types of countries, (2) to refrain from exporting arms even to countries that do not fall in any of these categories and (3) to consider manufacturing machines necessary for arms production in the same way as the arms themselves. ${ }^{31}$ In this way, Japan established a de-facto embargo on arm exports except when the specific project was approved on a strictly case-by-case basis. In December 2011, however, the Japanese government reviewed and modified this policy in light of a growing international trend of joint capability developments (such as for example the F-35) and a shrinking domestic defense industry. ${ }^{32}$ The new policy allowed to (1) transfer equipment to

\footnotetext{
28 "Australia and Japan-Cooperating for peace and stability: Common Vision and Objectives", Joint Statement of $4^{\text {th }}$ Australia-Japan Foreign and Defence Ministerial Consultations, 14 September 2012, at http://www.mod.go.jp/j/press/youjin/2012/09/14_js_e.html

${ }^{29}$ Medeiros, Evan S: "Strategic Hedging and the Future of Asia-Pacific Stability",The Washington Quarterly, vol. 29, no. 1 (2005), p. 145.

${ }^{30}$ MOFA: "Buki yushutsu sangen sokuto", at http://www.mofa.go.jp/mofaj/gaiko/arms/mine/sanngen.html.

${ }^{32}$ Government of Japan: "Boei sobihin to no Kaigai iten ni kan suru kijun ni tsuite no kanbo chokan danwa", at
} 
foreign countries when necessary for international peace cooperation missions and (2) international joint developments and productions with countries which maintained security cooperation with Japan. This opened up the possibility of joint development with foreign countries including Australia.

Second, Australia sees Japan as a potential support for its on-going submarine development project. In the Defence White Paper of 2009, the Australian government announced the plan called SEA1000, which aims at introducing twelve new conventionally powered submarines to replace the current fleet of six Collins class submarines. ${ }^{33}$ Since this announcement however, it has been revealed that Australia faces a significant shortage in skills, technologies and material infrastructure necessary for developing the planned submarines on schedule, forcing thus the government to delay the scheduling of SEA1000. As the government-commissioned report suggests, Australia is currently seeking support from foreign partners to fulfill the planned construction of the SEA1000 submarines, cooperating with companies such as Kockums in Sweden, DCNS in France, HDW in Germany, Navantia in Spain and Japan's Technical Research and Development Institute (TRDI). ${ }^{34}$ In this context, Japan's submarine technology clearly stands out. Compared to significantly smaller European submarines that have a much narrower operational range than that of Australia, Japan's submarine is much larger and is suitably designed to operate in as wide a theatre as the Western Pacific. ${ }^{35}$ For this reason, Japan and Australia recently opened bilateral talks on the possibility of equipment cooperation. The Vision Statement released in September 2012 after the two plus two meeting, for the first time included references to technology and equipment cooperation and both countries are in fact already maintaining close talks to establish a framework agreement to steer future cooperation on capabilities. ${ }^{36}$

At the first glance, Japan's assistance of Australia to acquire more sophisticated submarines might appear to be a form of external balancing or hedging. Indeed, one of the two primary rationales which Australia's Defence White Paper 2009 mentions for the introduction of a larger and more robust submarine fleet is to be ready for a major power war in the region in which Australia may be asked by its allies to assume operational roles. ${ }^{37}$ Since there is no other conceivable prospect for war between Australia's allies and a major power in the region except that between the U.S. and China, it is safe to assume that the Australian submarine development program is at least partly directed against China. If this is the case, could ongoing Japan-Australia talks on technology and equipment cooperation be considered as the former's contribution for the latter's hedging vis-à-vis China?

One should not overlook, however, two significant caveats to such interpretation. One of them has to do with Japan's real intentions when fostering technology and equipment cooperation with Australia; is Japan's policy's real objective to help Australia muscle up its military capability against China? Should it be on the contrary considered in more symbolic terms with Japan seeking to publicly demonstrate the closeness of their bilateral relations by pursuing a new and promising agenda? Or is maybe Japan's goal to simply gain tangible economic and technological benefits from Australia? The second limit to the argument of Japan-Australia capability cooperation as joint cooperation for hedging against China regards

http://www.kantei.go.jp/jp/tyokan/noda/ icsFiles/afieldfile/2012/03/13/20111227DANWA.pdf

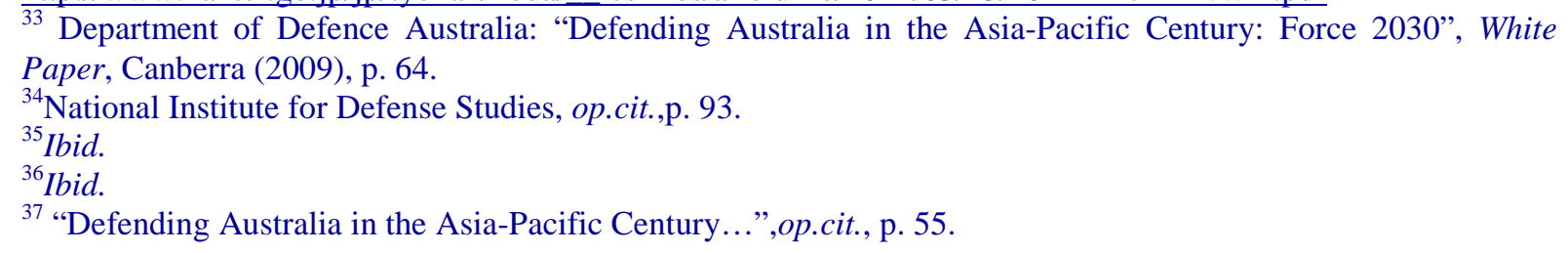


the current status of cooperation. At the time of writing this paper, Japan and Australia are still in the process of agreeing on the terms for pursuing cooperation, namely, how and to what extent will Japan be able to assist Australia's SEA1000, so much still remains undetermined. This cooperation is arguably still not sufficiently developed as to be already considered as a hedging policy towards China. We need in fact to clarify these two questions regarding Japan's intentions and real role in assisting Australia's submarine capability development, before claiming that Japan-Australia capability development is effectively an act of hedging vis-à-vis China.

Another aspect that also deserves analytical attention are joint exercises and trainings. Can this be considered as an example of Japan-Australia bilateral hedging vis-à-vis China? What is unequivocally clear is that the two countries have already conducted a variety of joint trainings and exercises. As this paper already mentioned, MSDF/RAN have undertaken joint trainings and exercises on a regular basis including Nichi-go Trident. ${ }^{38}$ Nichi-go Trident is a bilateral maritime training, the first round of which involved an anti-submarine warfare exercise in 2009. Nichi-go Trident has been taking place since then. In the case of ASDF/RAAF exchanges, both sides held their first bilateral training in Alaska in 2011 where fighter aircraft of both countries were successfully deployed and where they conducted an air combat exercise. ${ }^{39}$ The significance of these exercises should be contextualized before relating it to the Chinese factor and certain constraints taken into account. First, the current legal stance of Japanese government is that Japan is prohibited from exercising the right of collective self-defense. Thus, the fact that Japan and Australia conduct joint air combat exercises or anti-submarine warfare trainings does not automatically mean that Japan is ready to fight together with Australia. Second, Japan and Australia have signed no agreement as for where and in which situation they may be able to fight together. Because of these clear limitations, considering the Japan-Australia bilateral exercises as evidence of a joint hedging vis-à-vis China would be too simplistic.

To sum up, the argument that Japan and Australia pursue some kind of bilateral hedging vis-à-vis the rise of China is limited by existing constraints and the not yet fully developed potential for cooperation. Pursuing cooperation on capabilities and maintaining frequent exercises is a highly symbolic element that may thus contribute to show the advanced state of bilateral cooperation to any international audience including China, and if current efforts are actively maintained in the future, a day may come when Japan and Australia pursue a common military build-up and engage in joint exercises with clearer expectations of real joint operational situations. Until this happens, this will remain in the realm of speculations and in no case should a future potential be mixed with the description of the current reality in which many constraints limit bilateral security cooperation. In this light, it is clear that the characterization of Japan-Australia security relations as a bilateral endeavor to hedge the rise of China is exaggerated.

\section{Japan-Australia "Bilateral-Plus" Approaches Towards China}

Should we then consider that Japan-Australia relations can be seen largely unrelated to the rise of China? Is the bilateral partnership which engages in joint efforts as for example the

\footnotetext{
${ }^{38}$ National Institute for Defense Studies, op.cit.,p. 88.

${ }^{39}$ Ministry of Defence of Japan: "Beikugu nenshu hen o sanka oyobi beikoku ni okeru nichigo kyodo kunren no jisshi ni tsuite" (22 June 2011), at http://www.mod.go.jp/asdf/pr_report/houdou/H23/0622.html.
} 
United Nations Mission on South Sudan (UNMISS) a merely practical framework of cooperation only aimed at achieving the stabilization of a newly born African country? This purely practical understanding of Japan-Australia security relations is also too narrow an account. In fact, if one steps back and overviews Japan-Australia cooperation in broader contexts, it becomes clear that the two countries do pursue a joint policy aimed at China beyond strictly bilateral cooperation through what can be called "bilateral-plus" frameworks. There are at least three approaches that Japan and Australia employ in this respect:

\section{1. "Bilateral-Plus" Approach 1: Bilateral Dvad Embedded within Wider Multilateral Engagements with China}

One example of Japan-Australia "bilateral-plus" approaches towards China is their joint support for multilateral efforts to engage China, particularly in the Asia-Pacific region. Of course, the oldest example in this context is the creation and expansion of APEC in the late 1980s to early 1990s. But there are more recent examples as well. One of them is the creation and expansion of the East Asia Summit (EAS). In the process of the EAS launching in 2005, Japan had been a consistently strong advocate of both the idea of expanding the membership beyond the original ASEAN Plus Three (APT) countries to include Australia, New Zealand and India into the EAS. Japan's efforts in this regard were not limited to intensive diplomatic campaigns to convince other regional countries as they also translated into a tangible support for Australia. One of the issues which made the Howard Government initially reluctant about the EAS was the existence of the Treaty of Amity and Cooperation (TAC), the signing of which was set by ASEAN as one of the criteria to be included in the EAS. ${ }^{40}$ The issue was that it remained unclear what sort of implications TAC would have upon Australia's obligations under the ANZUS treaty. ${ }^{41}$ It was Japan precisely who provided Australia its own legal studies where it was concluded that TAC would have no negative implications as for its treaty obligations with the U.S. Japan's such support thus decisively helped pave the way for Australia's signature of the TAC and inclusion in the EAS as a founding member, ${ }^{42}$ even if of course, other countries such as India and Singapore also played an important role in expanding the EAS. In this sense, Japan-Australia cooperation should be considered as part of a wider multilateral efforts.

The ramifications of this multilateral effort turned out to be far reaching. The inclusion of Australia, India and New Zealand established a good precedent showing that the EAS was open to other countries outside of the original ASEAN plus China, Japan and South Korea core group of countries. In addition, the criteria used for Australia's entrance into the EAS set the standard for conditions, including signing of the TAC, any other countries wishing to enter the EAS would have to satisfy. These precedents surely helped the Obama Administration to consider entering EAS, which eventually happened in 2011.

The importance of these multilateral efforts are countless and potentially huge as they allow the regional countries to engage China on various issues including the maritime codes of conducts, transnational security issues, practical military to military exchanges and the regular leader's level communications. In this sense, Japan-Australia cooperation within multilateral contexts is an integral part of their China engagements. And of course, such efforts can be also seen in other institutions including ASEAN Defence Ministers' Meeting Pus and Western Pacific Naval Symposium.

\footnotetext{
${ }^{40}$ Terada, Takashi: "The origins of ASEAN+6 and Japan's initiatives: China's rise and the agent-structure analysis", The Pacific Review, vol.23, no.1 (March 2010), pp. 83-84.

${ }^{41}$ Ibid.

${ }^{42}$ Ibid.
} 


\section{2. "Bilateral-Plus" Approach 2: Active Cooperation with the United States}

Second, by far the most important expression of such "bilateral-plus" approaches is the two countries' joint support for U.S. regional engagement and presence. Japan and Australia are well positioned for assistingin that regard: with the effective installation of both ACSA and ISA between Japan and Australia, all the sides of Japan-Australia-U.S. triangle have now these legal infrastructures. In this context the defense leaders of the three countries released a joint statement in 2012 and agreed to create a joint action plan for a "strong dynamic and flexible" partnership. ${ }^{43}$ Such action plans will improve trilateral cooperation which has already a strong record of practical cooperation as demonstrated in their disaster relief collaborations in response to the Boxing Day Tsunami in 2004 and the Great East Japan Earthquake 2011.

Another area of trilateral cooperation far more substantial than the Japan-Australia bilateral trainings are the active trilateral exercises: the three countries have for example conducted the Pacific Global Air Mobility Seminar (PGAMS), which evaluates trilateral transportation cooperation among Japan, the United States, and Australia. ${ }^{44}$ In the 2007 PGAMS, such aircraft as US Air Force C-17 and ASDF C-130 were displayed and each of the three countries provided relevant briefings about the transportation operation at the Yokota Air Base in Japan. Later in February 2008, the three countries gathered again in another PGAMS meeting in which a USAF $\mathrm{C}-17$ transport aircraft performed the loading of $\mathrm{CH}-47$ helicopters of the Ground Self Defense Force (GSDF). ${ }^{45}$ More recently in June 2012, for the purpose of enhancing trilateral HA/DR and PKO cooperation, the Australian Army participated for the first time in a Senior Level Seminar between the GSDF, the US Army and Marines. These peacetime trilateral commitments have already given early fruits. ${ }^{46}$ One of the ADF officers who participated in PGAMS happened to take part in the ADF's disaster relief operation in the wake of Great East Japan Earthquake. ${ }^{47}$ This was fortunate because that officer contributed a lot to the effective cooperation among Japan, Australia and the U.S. proving thus the importance of the aforementioned peacetime activities.

These practical trilateral activities in nontraditional areas can help the U.S. in three ways. First is burden-sharing: ${ }^{48}$ Effective and efficient trilateral cooperation will help reduce the burden upon the shoulders of a declining superpower which for a long time has played a dominant role as a provider of international public goods. Furthermore, even if burdensharing is pursued in non-traditional security areas, its implications are far-reaching. Trilateral burden-sharing in such activities as PKO and HA/DR allows the U.S. to allocate more resources into other agendas including more traditional mission areas. Second, visible cooperation among the U.S. and its allies demonstrates its solidity to various audiences including U.S. domestic actors. Third, conducting HA/DR and PKO more effectively, will

\footnotetext{
${ }^{43}$ U.S. Department of Defense: "Joint Statement of the U.S.-Australia-and Japan Meeting at Shangri-La", News Release, 2 June 2012, at http://www.defense.gov/releases/release.aspx?releaseid=15338.

${ }^{44}$ National Institute for Defense Studies, op.cit.,p. 89.

${ }^{45}$ Ibid.

${ }^{46}$ Ibid.

${ }^{47}$ Gellel, Timothy: "An Australian Defence Force Perspective of the Humanitarian Assistance and Disaster Relief Response to the 11 March 2011 Great East Japan Earthquake and Tsunami, and Nuclear Crisis", in National Institute for Defense Studies (eds.) (2012): International Symposium on Security Affairs 2011, Tokyo, Urban Connections, pp. 47-57.

${ }^{48}$ For the updated theoretical discussions on the concept of burden-sharing, see Satake, Tomohiko: "Japan, Australia and International Security Burden-Sharing with the United States", in Tow, William; Kersten, Rikki (eds.) (2012): Bilateral Perspectives on Regional Security: Australia, Japan and the Asia-Pacific Region, Australia, Palgrave MacMillan, pp. 183-244.
} 
help strengthen the regional standing of the U.S. For example, the swiftness and visibility of the Disaster Relief activities will surely contribute to improve the public image of the United States in disaster-stricken countries and will in turn allow the U.S. to come even closer to these countries.

Of more timely relevance in this context is the fact that these active patterns of cooperation among the three countries have become increasingly important from the perspective of the Obama Administration's "rebalancing" towards the Asia-Pacific. ${ }^{49}$ One of the main features of this rebalancing policy is its emphasis on U.S. Armed Forces' regional activities as a key element of the U.S. presence. For example, one of the concrete policy outcomes produced by Obama's Asia-Pacific strategy has been U.S. Marines rotational deployment to Darwin and its Air Force's increasing access to Northern Australia. The first round of the Marines rotational deployment was already implemented from April to September of 2012, when the deployed company-size Marines unit engaged in joint trainings with Southeast Asian countries. The U.S. enhances its regional presence deliberately avoiding the creation of any new U.S. bases and chooses instead to rely on its allies (as opposed to forward-deployed presence through permanent bases overseas) as a source of presence for at least two reasons: First, an increasingly difficult fiscal situation does not allow the Obama Administration to additionally establish costly bases. ${ }^{50}$ Second, as history shows, establishing its own bases has often complicated America's relations with its host countries. ${ }^{51}$ In any case, if the U.S. rebalancing strategy increasingly relies on the active engagement through joint trainings as it is the case of the Japan-Australia-U.S. trilateral cooperation, these active exercises and nontraditional military operations will become only more important.

To what extent can all this be regarded as a China-targeting policy? Supporting the U.S. regional presence contributes in many ways to managing the rise of China. For one, its strong regional standing allows the U.S. to engage with China from a position of confidence and strength. For another, the credibility of the U.S. regional commitment is an essential part of the foundation for the U.S. regional alliance system, which plays a vital role in deterring Chinese activities on many fronts. What is more, perhaps the third and least visible role played by the U.S. in dealing with the impact of China's rise is through reassuring Japan. In fact, part of Australia's intention in pursuing trilateral cooperation is to assist the U.S in this reassurance function. One former official of the Australian Department of Defence revealed the internal discussions about Australia's approaches to Japan. ${ }^{52}$ In the 1990s when Australia increased its approaches to Japan, there was a growing recognition inside the government of the strategic significance of the U.S.-Japan alliance. ${ }^{53}$ That is, amidst the rise of China, one of the core functions of the alliance was to provide strategic reassurance to Japan, increasingly facing a rising neighbor. ${ }^{54}$ In Australia's view, this reassurance function helps prevent an extensive Sino-Japanese rivalry from emerging and disrupting the regional order. ${ }^{55}$ In this context, Australia judges that it is in its national interest to support Japan's expanding involvement within the alliance and becoming a more active partner for the U.S., as this would no doubt strengthen the U.S.-Japan alliance, which in turn helps reassure Japan about

\footnotetext{
${ }^{49}$ Satake, Tomohiko and Ishihara, Yusuke: “America's Rebalance to Asia and its Implications for Japan-USAustralia Security Cooperation”, Asia-Pacific Review, vol.19, no. 2 (2012), pp. 6-25.

${ }^{50}$ Ibid.

${ }^{51}$ Ibid.

${ }^{52}$ White, Hugh: "Trilateralism and Australia: Australia and the Trilateral Strategic Dialogue with America and Japan", in Tow; Thomson; Yamamoto and Mimaye, op.cit., p. 104.

${ }^{53}$ Ibid.

${ }^{54}$ Ibid.

${ }^{55}$ Ibid.
} 
the rise of China. In this respect, the Japan-Australia-U.S. trilateral cooperation is, from the Australian perspective, a means to assist the alliance in its core function of containing JapanChina rivalry.

There is however one note of caution. Supporting the U.S. engagement in the region does not have to be done through trilateral patterns of cooperation and neither is it necessary that cooperation takes place only within the realm of security. Quite on the contrary, multilateral cooperation on economic agendas can serve the same purpose. The Trans Pacific Partnership (TPP) for example, sheds some light on this. As the Obama administration has repeatedly emphasized, the US economic cooperation with regional economies is also an important pillar for its regional engagement. To put an example, figures are eloquent enough when they show that in 2011 about $25 \%$ of U.S. exports went to East Asia, while about $35 \%$ of the imports to the U.S. also came from East Asia. ${ }^{56}$ Thus the U.S. regional presence should be enhanced by a future conclusion of the TPP. ${ }^{57}$ Although the current Abe Government is still negotiating with futureTPP participant countries including Australia, Japan's potential participation in this partnership should open another venue for Japan and Australia to strengthen the U.S. economic presence in the Asia-Pacific region.

\section{3. "Bilateral-Plus" Approach 3: Capacitv-Building Cooperation for Third Countries}

On top of these long standing "bilateral-plus" policies, there is an emerging third approach which is joint assistance to the development and capacity-building of third countries. Especially in the case of Japanese Ministry of Defense, capacity-building assistance has been established as a new mission item since the National Defense Program Guidelines 2010. The Japanese Government has already started implementing capacity-building through assistance for vehicle maintenance skills in East Timor, education provision regarding engineering skills in Cambodia and medical education in Vietnam. ${ }^{58}$ In the case of Australia, capacity-building activities have been since long a mission area for the Department of Defence and the Australian Defence Force.The best example is the Pacific Patrol Boat (PPB) program, which Australia started in the South Pacific Region in the 1980s. ${ }^{59}$ The trigger was the adoption of the United Nations Convention on the Law of the Sea (UNCLOS) at the UN General Assembly in 1982. That prompted Australia to assist the small island countries in the Pacific to effectively govern their vast Exclusive Economic Zone (EEZ). In this context, the PPB was initiated to provide these Pacific insular states with patrol boats and a maintenance service as well as all necessary trainings so that they could effectively control their EEZs. This helped stabilize Australia's immediate neighborhood as well as promote effective governance for the global maritime regime.

Of course, capacity-building cooperation still remains largely unimplemented in many respects where the two countries are nevertheless involved in discussions. But if it is fully carried out, capacity building cooperation will help other countries assume more active roles in their own domestic governance and eventually improve international security if it may help increase the number of capable supporters of international rules and principles such as

\footnotetext{
${ }^{56}$ Data Page on the United States in the website of Japan External Trade Organization, at http://www.jetro.go.jp/world/n_america/us/stat_01/

${ }^{57}$ Prime Minister Shinzo Abe made the point about the security implications of TPP. See "Abe shusho TPP hamasa ni kokka hyakunen no keida kankei kakuryo kaigide", Asahi Shimbun, 12 April 2013, at http://digital.asahi.com/articles/TKY201304120354.html?ref=comkiji_txt_end_kjid_TKY201304120354.

${ }^{58}$ For the information on the past and current capacity-building projects, see the following page of Ministry of Defense Japan, at http://www.mod.go.jp/j/approach/exchange/cap build/.

${ }^{59}$ National Institute for Defense Studies, op.cit.,p. 77.
} 
freedom of navigation and maritime rights especially amidst the rise of the "Chinese dragon" which occasionally expresses unease with the existing order.

\section{Divergence about China and Convergence about International Order}

This paper has so far put forth the argument that Japan-Australia joint China approaches are developing largely in a "bilateral-plus" pattern including trilateral formats and wider multilateral contexts whereas the strictly bilateral efforts remain either limited, underdeveloped or constrained. Why is this the case? The key question in examining this issue is to what extent Japanese and Australian perceptions with regard to China converge or diverge. It is important in this context to note that there are both elements of divergence and convergence in their views onChina's rise.

The main element of divergence lies in the visible differences between their China policy. On the one hand, given geographic proximity and long standing issues in their bilateral relations, Japan has a much more acute sense of risks about China. Such perceptions about China are reflected in the National Defense Program Guidelines 2010 (NDPG2010). ${ }^{60}$ NDPG2010 introduced the new concept of Dynamic Defense Force envisioning a Self Defense Force able to conduct a range of operational activities on a more swift, more sustainable and more seamless way. What does this mean? A large part of the thinking behind the Dynamic Defense Force concept is Japan's appraisal of its strategic environment. NDPG2010 uses the term "gray zone" to describe the strategic environment facing Japan which is understood as a security limbo situation between completely calm peacetime conditions and outright war. The "gray zone" condition is the situation in which SDF is required to conduct and sustain operations at a high tempo in order not to fight in a large-scale conventional war but taking at the same time part in various peacetime activities such as, for example, SDF's Intelligence, Surveillance and Reconnaissance (ISR) activities meant to check Chinese increasing naval activities in the waters surrounding Japan. The "gray zone" appraisal of the strategic environment has required Japan to build a Dynamic Defense Force capable of conducting various activities on a swift, sustainable and seamless way. In retrospect, NDPG2010's description of Japan's strategic environment as well as its vision for the SDF to become a Dynamic Defense Force was very well adapted to what would in fact happen in the following years, as when Chinese vessels started increasingly operating in the waters near Senkaku islands in East China Sea. In such situations, SDF too has been required to deploy both naval and air assets such as the surface combatants, P-3Cs and E2-Cs at a high tempo and for a longer duration. ${ }^{61}$

Of course, SDF's countermoves are only a part of Japan's overall China policy as Japan concurrently also seeks engagement with the rising dragon. This should be no surprise as China is Japan's leading trade partner and the two countries share a number of critical national interests such as the stability over the Korean Peninsula, peaceful development of regional economic cooperation, and tackling a range of nontraditional security issues. This is why Prime Minister Shinzo Abe has repeatedly said that Japan is open to dialogue with the Chinese side. And this is also the reason why Japan and China have been working together to create a maritime communication mechanism between their defense organizations in order to

\footnotetext{
${ }^{60}$ Satake, Tomohiko: “Japan's Security Outlook in 2011: Toward a More "Dynamic” Defense Posture", in Katahara, Eiichi (eds.) (2012): Security Outlook of the Asia Pacific Countries and its Implications for the Defense Sector, Tokyo, Urban Connections, pp. 137-154.

61 “Japan Chapter", in National Institute for Defense Studies, op. cit., pp. 98-130.
} 
avoid accidental escalations. ${ }^{62}$ Despite Japan's hope to engage China, both high-level dialogues and working level negotiations for maritime communication mechanism are currently frozen (at the time of writing this paper) due to the continuing tension in the East China Sea.

Like Japan, Australia pursues a dual strategy of engagement and hedging, the substance of which, however, is significantly different from that of Japan. Prime Minister Julia Gillard's visit to China in April 2013, in which she met the newly elected Chinese President Xi Jiping and Premier Li Keqiang, materialized in the historic achievement of annualizing bilateral leadership meetings including Prime Ministerial meetings, Strategic Economic Dialogue of Treasurer and Finance Minister, and Foreign Minister-led dialogue. ${ }^{63}$ This is a tremendous diplomatic success that few other countries have achieved resulting from Australia's longtime efforts. Although negotiations for deepening institutionalization started in April 2012, Australia's efforts to engage with China started much earlier, as can be demonstrated by the regularization of defense and foreign ministerial meetings, military to military joint exercises including live-fire exercises and joint Search and Rescue (SAR) training between the two Navies since September 2010, followed by the SAR and communication training in May 2012, and the series of HA/DR training first in Sichuan Province of China, in November to December 2011 and again in Australia in October 2012. ${ }^{64}$

The contrast between Australia's visible success and Japan's continuing struggle for even resuming leaders' level communication is no surprise given that Japan faces a number of risks derived from the rise of China, while Australia can afford far more stable relations. This however, is far from meaning that Sino-Australian relations are completely immune to controversies. Quite on the contrary, bilateral relations have hit several bumps from time to time, as when for example the Australian employees of Rio Tinto were arrested in 2008 and when Uyghur leader Rabiye Kadeer visited Australia in $2008 .^{65}$ On balance, however, these issues never damaged bilateral relations as seriously as the current tensions in the East China Sea are currently harming Japan-China relations. In this sense it is fair to note that there is a clear and perhaps natural gap between Japan and Australia in terms of their respective bilateral approaches to China. Because of such visible differences in their engagement and hedging vis-à-vis China, it appears only natural that there are certain limits and impediments that have to be overcome if Japan and Australia aim to pursue bilateral cooperation vis-à-vis China in more direct, effective and explicit manners.

Despite this divergence, however, there also exists a clear convergence in both countries' thinking about the rise of China. Even though Japan and Australia have significantly different relations with China, their views are closely aligned when it comes to the broader question of what type of international order Japan and Australia aim to preserve and promote amid the historic rise of China. This is expressed in at least three interrelated aspects.

First, Japan and Australia agree regarding the importance of their respective alliances and hence support the U.S. role in the Asia-Pacific region. Although some scholars argue that

\footnotetext{
${ }^{62}$ For the publicly available information on the first, second and third meetings on a maritime communication mechanism between Japan and China, see the page of Ministry of Defense Japan, at http://www.mod.go.jp/j/approach/exchange/nikoku/asia/china/kaijou_mechanism.html

63 "Transcript of Joint Press Conference", Press Office of Prime Minister, Beijing (9 April 2013), at http://www.pm.gov.au/press-office/transcript-joint-press-conference-43

${ }^{64}$ National Institute for Defense Studies, op.cit. pp. 81-82.

${ }^{65}$ Ibid., pp. 82-83.
} 
the rise of China makes the alliance no longer valid, Japanese and Australian governments disagree. The Abe Government of Japan is currently engaged in a series of initiatives to further strengthen the alliance with the U.S. including an on-going review about the interpretation on the Constitution and more specifically the right of collective self-defense. The motivation behind this move is partly related to Japan's recognition that the rise of China on the contrary makes the U.S. and the alliance even more important. ${ }^{66}$ Japan also cooperates with the U.S. through wider regional cooperation such as in the annual Cobra Gold exercise, the Pacific Partnership activities, Khan Quest exercises, trilateral engagements with India and South Korea and so forth. Through this activities, Japan explores ways for supporting U.S. engagement within the Asia-Pacific region.

Similarly, Australia has also been moving to enhance its alliance with the U.S. In November 2011, President Barrack Obama and Prime Minister Gillard made the announcement that the two countries would start cooperating on the Force Posture Initiative, which includes the deployment of rotational Marines in Darwin and enhanced access for U.S. Air force to Northern Australia as this paper already mentioned earlier. ${ }^{67}$ The purpose of this allied cooperation is largely the re-affirmation of Australia's long-standing policy to assist the U.S. in its regional engagements. In the joint press conference with President Obama, Prime Minister Gillard noted: "We live in a region which is changing, changing in important ways. And as a result of those changes, President Obama and I have been discussing the best way of our militaries cooperating for the future". ${ }^{68}$ What Prime Minister Gillard meant is that the Australian government intends to maintain its support for the alliance both in words and in concrete deeds. Australia also aims at further cooperating with the U.S. in the face of China's rise.

Japanese and Australian governments' policies of strengthening the alliance with the U.S. amid the ongoing power shift in the region are closely aligned. In fact, this convergence is reflected in the Japan-Australia Vision Statement issued in September 2012 suggesting that it is in their joint interest to ensure "mutual support for our respective alliances with the United States, which continue to help underwrite peace, stability and prosperity in the AsiaPacific, and work together as active partners to maintain and strengthen comprehensive US engagement in the region". 69

The second element of Japanese and Australian common view about the international order can be seen in their joint support for a liberal international order, which is seen to have underwritten peace and prosperity since the end of the Second World War. Prime Minister Abe's major policy speeches all underscored Japan's longstanding support for a liberal international order underpinned by such principles as freedom of navigation and commerce on the maritime domain, flourishing economic relations, human security, rule of law, common international rules and so forth. ${ }^{70}$ Far from a merely personal orientation, Prime Minister Abe's such stance is widely shared in Japan as an essential part of the country's foreign

\footnotetext{
${ }^{66}$ Prime Minister Abe made this point at one of the Prime Ministerial policy review committees. See:http://www.kantei.go.jp/jp/96_abe/actions/201302/08anzenhosyo.html

67"Remarks by President Obama and Prime Minister Gillard of Australia in Joint Press Conference", at http://www.whitehouse.gov/the-press-office/2011/11/16/remarks-president-obama-and-prime-minister-gillardaustralia-joint-press.

${ }^{68}$ Ibid.

69، Australia and Japan-Cooperating for peace and stability: Common Vision and Objectives", Joint Statement of $4^{\text {th }}$ Australia-Japan Foreign and Defence Ministerial Consultations (14 September 2012), at http://www.mod.go.jp/j/press/youjin/2012/09/14_js_e.html.

${ }^{70}$ For example, see his speech prepared for his address at CSIS Indonesia, at http://www.mofa.go.jp/announce/pm/abe/abe 0118e.html
} 
policy. Likewise, Australia's Gillard government also repeatedly stresses the importance of a liberal international order. For example, her government's White Paper "Australia in the Asian Century" and the National Security Strategy report both note that even though there are some uncertainties arising from the changes taking place in international politics, as the rise of China, Australia remains confident because of the existence of international and regional institutions, economic interdependence, and diplomatic ties in the Asia-Pacific region and beyond. $^{71}$

Lastly, Japan and Australia hold a common view on the importance of supporting other countries' increasingly active roles on the regional and global stages and the need to develop closer ties with them. Reflective of this are Japan's growing efforts in creating a wide network of security relations with such countries as India, Indonesia, Vietnam, the Philippines and South Korea (though it is not a smooth pathway). ${ }^{72}$ Furthermore, Japan's efforts through the long-standing Official Development Assistance and the newly initiated defense capacitybuilding is a clear evidence of Japan's support for numerous countries for increasing their international protagonism. As one of the government commissioned reports about Japanese security and defense policies explains, by building a network of cooperation and helping other countries to play a bigger role, Japan attempts to increase support for a liberal international system. ${ }^{73}$ Similarly, Australia emphasizes the importance of recognizing the other rising powers such as India, Indonesia and many other Southeast Asian countries. In fact, Australia has been an energetic promoter of its own regional relations by, to name just a few examples, institutionalizing the relationship with India, initiating annual leaders' summits as well as regular two plus two meetings with Indonesia, and making joint security statements and establishing two plus two meetings with South Korea. ${ }^{74}$

Common views about the importance of the U.S. regional engagement, the liberal character of international order and the active roles played by other partners are the foundation for Japan-Australia "bilateral-plus" approaches. Because the two countries agree on the continuing importance of the U.S. engagement in the region including their own alliances amidst the rise of China, it appears only natural that Japan and Australia go beyond a narrow bilateral relation and establish a trilateral framework including the U.S. Similarly, given that the importance of the liberal elements in the current international order is commonly recognized not just by Japan and Australia alone but by many other like-minded countries too, it is again only natural that the Japan-Australia partnership is deeply woven into wider multilateral collaborations such as EAS, ADMM plus, Lower Mekong Imitative and so forth. In other words, Japan-Australia convergent views about international order are so broad that other countries often share them. If so, embedding the bilateral cooperation into broader, either trilateral or multilateral, contexts is a more optimal approach than confining themselves within a narrow bilateral framework.

\footnotetext{
${ }^{71}$ Commonwealth of Australia (2012): “Australia in the AsianCentury", White Paper, Canberra, (2012).

${ }^{72}$ Sahashi, Ryo: "Conceptualising the Three-Tier Approach to Analyse the Security Arrangements in the AsiaPacific", SDCS Working Paper, no. 415 (December 2009).

${ }^{73}$ Government of Japan: “The final report of The Council on Security and Defense Capability”, September 2009, at

http://www.kantei.go.jp/jp/singi/ampobouei2/200908houkoku.pdf

${ }^{74}$ For example, see: “Joint Communique- ${ }^{\text {st }}$ Indonesia-Australia Annual Leaders' Meeting”(20 November 2011), at http://www.pm.gov.au/press-office/1st-indonesia-australia-annual-leaders-meeting-joint-communique.
} 


\section{Conclusion}

This article argues that Japan-Australia security relations can be considered as a joint policy towards a rising China, when we go beyond the bilateral context and consider broader "bilateral-plus" frameworks as trilateral cooperation with U.S., multilateral engagements with China and joint assistance to third countries. In its conclusion, this paper sees two modest implications for the current debate about Japan-Australia relations. First, to claims that JapanAustralia cooperation pursues hedging, containment and balancing against China, the paper's response is indirectly yes, but it also states that given the limited, constrained and underdeveloped character of their bilateral cooperation, bilateral relations can hardly be regarded as an effective way of hedging. However, Japan and Australia do cooperate for the purpose of at least indirectly hedging China as the two countries clearly support the U.S. engagement in the Asia-Pacific regionas well as other alliances which clearly play important roles in deterring some of Chinese activities. This is an indirect way of hedging against China as a close Japan-Australia partnership helps the U.S. to deterthe rise of China.

Second, the nature of the "bilateral-plus" approaches underlying Japan-Australia relations reflect a good deal of liberalism, not just realism. Although such concepts as hedging, containment, and balancing convey the impression that the Japan-Australia partnership is an expression of realism, much of what they jointly do in their "bilateral-plus" approaches to China is not necessarily realist-oriented. For example, Japan-Australia joint cooperation within the regional multilateral institutions offer a chance for the participant countries to discuss common issues with China, build personal relationships with Chinese leaders and bureaucrats, and in some cases even cooperate to create rules together with China. In this sense, any concept that aims at describing Japan-Australia cooperation vis-à-vis China should incorporate both realism and liberalism. ${ }^{75}$

Of course, this article concentrates largely on what has happened in the past and what is happening at present, but not how Japan-Australia relations will look like in the future; there is a variety of conceivable possibilities for Japan-Australia relations. For example, it is highly possible that Japan-Australia relations may become more realist vis-à-vis China than this paper has described. If the U.S. starts demanding its allies to take part in countering Chinese Anti-Access and Area-Denial capability, they may encourage Japan and Australia to enhance their interoperability far beyond the current level. If Japan is going to modify its current legal position about the right of collective self-defense, it becomes possible for two countries to cooperate more closely in conventional military scenarios. In the eyes of those who assume that this will happen in the future, Japan-Australia current efforts to build closer ties may appear to be only a first step for such future cooperation. This paper does not deny any of those possibilities because the aim of the paper is not to make predictions but to find out what Japan and Australia are doing and achieving together now. The "bilateral-plus" approaches are not a future prospect but an on-going policy that the two countries pursue together right now.

\footnotetext{
${ }^{75}$ For example, Michael Green and Daniel Twining offer an argument reflecting this point, even though their analysis does not necessarily examine Japan-Australia relations in detail. See: Green, Michael J. and Twining, Daniel: "Democracy and American Grand Strategy in Asia: The Realist Principles Behind an Enduring Idealism”, Contemporary Southeast Asia, vol. 30, no. 1 (2008), pp. 1-28.
} 